\title{
Environmental responsibility and pro-environmental behavior: Biology undergraduate students' profile
}

\author{
Diana Vivanti Sigit a,1, , Eka Putri Azrai a,2, Erna Heryanti a,3 , Kasih Anggraeni a,4 , Ilmi Zajuli \\ Ichsan ${ }^{a, 5}$, Rahmat Fadrikal b,6 \\ a Department of Biology Education, Faculty of Mathematics and Natural Science, Universitas Negeri Jakarta, JI.Rawamangun Muka, \\ the Special Capital Territory of Jakarta (DKI, Jakarta) 13220, Indonesia \\ ${ }^{b}$ Department of Biology Education, Faculty of Teacher Training and Education, Universitas Sultan Ageng Tirtayasa, Jl. Ciwaru Raya \\ No. 25, Serang, Banten 42117, Indonesia \\ dianav@unj.ac.id*; ${ }^{2}$ ep_azrai@yahoo.com; ${ }^{3}$ erna.heryanti@gmail.com; ${ }^{4}$ kasihanggara@gmail.com; ${ }^{5}$ ilmi.zajuli@outlook.co.id; \\ ${ }_{6}^{6}$ fadrikal@gmail.com \\ * Corresponding author
}

\begin{tabular}{|c|c|}
\hline ARTICLE INFO & ABSTRACT \\
\hline \multirow[t]{2}{*}{$\begin{array}{l}\text { Article history } \\
\text { Received March 10, } 2019 \\
\text { Revised June 15, } 2019 \\
\text { Accepted June 22, } 2019 \\
\text { Published June 30, } 2019 \\
\\
\text { Keywords } \\
\text { Biology undergraduate student } \\
\text { profile } \\
\text { Environmental responsibility } \\
\text { Pro-environmental behavior }\end{array}$} & $\begin{array}{l}\text { Environmental responsibility is a crucial aspect which determines the environmental } \\
\text { solving problems in term of enhancing the pro-environmental behavior. This study } \\
\text { aimed to examine the relation between the environmental responsibility and pro- } \\
\text { environmental behavior of the undergraduate students. The sample of this descriptive } \\
\text { correlational study was } 106 \text { students of biology education department which was taken } \\
\text { randomly. This study showed that the undergraduate students were in high criteria of } \\
\text { environment responsibility (ER). This was represented by feeling guilty which was the } \\
\text { highest percentage and followed by responsibility feeling and responsibility judgment } \\
\text { respectively. In addition, the undergraduate students were in positive pro-environmental } \\
\text { behavior (PEB). The regression model was y }=23.876+0.623 x \text {; while ER contributed } \\
\text { as high as } 22.1 \% \text { to the undergraduate student's PEB. This implied that to improve the } \\
\text { undergraduate student's PEB is by strengthening their ER. }\end{array}$ \\
\hline & $\begin{array}{l}\text { Copyright } \odot \text { 2019, Sigit et al } \\
\text { This is an open access article under the CC-BY-SA license }\end{array}$ \\
\hline $\begin{array}{r}\text { How to cite: Sigit, D. V., Az } \\
\text { and pro-envirc } \\
5(2), 237-244 .\end{array}$ & $\begin{array}{l}\text { Heryanti, E., Anggraeni, K., Ichsan, I. Z., \& Fadrikal, R. (2019). Environmental responsibi } \\
\text { havior: Biology undergraduate students' profile. JPBI (Jurnal Pendidikan Biologi Indonesi } \\
\text { doi.org/10.22219/jpbi.v5i2.7831 }\end{array}$ \\
\hline
\end{tabular}

\section{INTRODUCTION}

The problem of environmental degradation has become the world's attention (Bronfman, Cisternas, LópezVázquez, De la Maza, \& Oyanedel, 2015; Choudri et al., 2017; Miller \& Bush, 2015). Environmental problems that often arise such as global warming, depletion of the ozone layer, accumulation of inorganic waste and environmental pollution by chemicals. Every country contributes to the destruction of the global environment, especially in big cities. Big cities experience problems such as river pollution, air pollution, and industrial waste problems (Aye \& Widjaya, 2006; Hama \& Hilal, 2017; Kanchanabhandhu \& Woraphong, 2016; Song, Li, Duan, Yu, \& Wang, 2017).

Environmental problems are complex problems that are interrelated with the emergence of other problems. This is due to high population growth, both caused by birth and urbanization. The main environmental problems 
in major cities in Indonesia include reduced water catchment areas, shrinking green open areas, damage to blue open areas (rivers, waterways and coastal waters), underground water exploitation, coastal abrasion due to loss of mangrove forests on the north coast, and a bad city drainage system (Gabarda-Mallorquí, Fraguell, \& Ribas, 2018; Lazaridou, Michailidis, \& Trigkas, 2018). This has become a special focus for environmentalists, many efforts can be made to minimize the adverse effects of the environment (Cooper, Larson, Dayer, Stedman, \& Decker, 2015; Steinhorst \& Klöckner, 2017).

The problem of environmental degradation as happened in Jakarta is caused by many factors in human behavior. Humans use natural resources available to meet their growing needs. Excessive exploitation of a commodity in a region will certainly damage the region. This is showed by the reduced diversity in the area and the depletion of natural resources there (Cooper et al., 2015; Margono, Potapov, Turubanova, Stolle, \& Hansen, 2014; Strange, Jellesmark, Bladt, Wilson, \& Rahbek, 2011).

Humans as subjects who can process natural resources have responsibility for the environment and various flora and fauna that exist on the face of the earth. This responsibility is called Environmental Responsibility (ER). In simple terms, ER is a behavior in which a human being is responsible for his daily behavior so that his environment can be maintained (Choudri et al., 2017; Lekakos, Vlachos, \& Koritos, 2014; Wong, Miao, Cui, \& Tang, 2018). The implementation of the ER can be started on a small scale, such as changing daily behavior to be more environmentally friendly or to be a loving behavior for the environment.

Meanwhile besides the ER needed, a human being is also required to have a Pro-environmental behavior (PEB) which is a behavior that is shown to be concerned with the environment (Durr, Bilecki, \& Li, 2017; Rezvani, Jansson, \& Bengtsson, 2017; Schmitt, Aknin, Axsen, \& Shwom, 2018; Tang, Geng, Schultz, Zhou, \& Xiang, 2017). People who have high PEB will definitely do everything by considering the environment. They will not act or do anything that is contrary to the environment in which they live.

Undergraduate students are young intellectuals and act as agents of change. Biology undergraduate students study the science of living things and their environment. Biology undergraduate students are expected to have a high ER because the ER is the main goal of environmental education. Therefore, biology undergraduate students are expected to be able to apply their knowledge to daily behavior as a PEB and socialize it to the public (Akenji, 2014; Buzov, 2014; Ichsan, Sigit, Miarsyah, Azrai, \& Heryanti, 2019; Jonell, Crona, Brown, Rönnbäck, \& Troell, 2016; Krettenauer, 2017). Previous research mostly examined ER and PEB in the community, but not specifically studied related to undergraduate students in the Biology study program (Du, Jian, Zeng, \& Du, 2014; Panno et al., 2017; Wong et al., 2018). This is a novelty of this research, which presents ER data and PEB undergraduate students in biology education programs. Based on various studies that have been conducted from various sources, it is suspected that there is a relationship between ER and PEB, in this case, the Biology Education undergraduate students. The purpose of this study was to determine the relationship between ER and PEB for Biology undergraduate students at Universitas Negeri Jakarta.

\section{METHOD}

The method used is descriptive survey research with independent variables $(X)$ is environmental responsibility $(E R)$ and the dependent variable $(Y)$ is the pro-environmental behavior $(\mathrm{PEB})$. This research was conducted at the Biology Education Study Program, Universitas Negeri Jakarta in January 2017. The population is undergraduate students from the 5th semester of the Biology education study program at the Universitas Negeri Jakarta. A sample of 106 undergraduate students was taken by simple random sampling.

The instrument used was the ER questionnaire consisting of 40 statements with dimensions including Responsibility Feeling, Feeling Guilty, Responsibility Judgment (Du et al., 2014; Kaiser, Ranney, Hartig, \& Bowler, 1999). The PEB questionnaire consists of 41 statements including energy conservation, transportation mobility, consumerism, waste avoidance, representative social behavior towards conservation and recycling according to what was stated by Kaiser \& Wilson (2004). Both instruments have been tested for validity and reliability and the instrument was declared valid and reliable. After that, data were analyzed by normality and homogeneity test, while data have normal distributed regression and linearity test can be use, but if data doesn't normal distribution, data analyze with non-parametric test (such as Spearman rank test). Hypothesis testing was analyzed by regression model and coefficient of determination between variables. The research hypotheses was there is a positive relationship between ER and PEB in Biology undergraduate Students.

\section{RESULTS AND DISCUSSION}

Most Undergraduate students (10+78\%) were shown to had very high and high levels of ER and $1 \%$ with low criterion as shown in Table 1. 
Table 1. Percentage of students who fall into each environmental responsibility criterion

\begin{tabular}{ll}
\hline Criteria & Percentage (\%) \\
\hline Very High & 10 \\
High & 78 \\
Moderate & 11 \\
Low & 1 \\
\hline
\end{tabular}

The distribution of biology undergraduate students in three ER indicators is shown in Table 2. The highest percentage was $42 \%$ for feeling guilty, while the indicator with the lowest percentage of $19 \%$ was the responsibility judgement. The remaining 39\% was for the responsibility feeling indicators

Table 2. Percentage of students categorized into the indicator for environmental responsibility

\begin{tabular}{ll}
\hline Indicators & Percentage (\%) \\
\hline Responsibility Feeling & 39 \\
Feeling Guilty & 42 \\
Responsibility Judgment & 19 \\
\hline
\end{tabular}

The majority of biology undergraduate students have a PEB score with positive criteria of $77.4 \%$, while $22.6 \%$ get negative criteria, as shown in Table 3 .

Table 3. Percentage of students who fall into alternative pro environmental behavior criterion

\begin{tabular}{ll}
\hline Criteria & Percentage (\%) \\
\hline Positive & 77.4 \\
Negative & 22.6 \\
\hline
\end{tabular}

PEB includes 6 indicators. The percentage of students categorized into each indicator is shown in Table 4. The indicator of PEB which had the highest percentage were energy conservation, transportation, and mobility of $19 \%$, while the indicator with the lowest percentage (13\%) was recycling. The rest were consumerism $(18 \%)$, waste avoidance (16\%) and representative social behavior towards conservation (15\%).

Table 4. Percentage of students categorized into the indicator for pro environmental behavior

\begin{tabular}{ll}
\hline Indicators & Percentage (\%) \\
\hline Energy Conservation & 19 \\
Transportation and Mobility & 19 \\
Waste Avoidance & 16 \\
Consumerism & 18 \\
Recycling & 13 \\
Vicarious, Social Behavior & 15 \\
\hline
\end{tabular}

On average, female students had a higher score for ER than male students. The average ER score of female undergraduate students was 98.70 while that of male students was 95.46 . The difference between the value of male and female was 3.24, as shown in Table 5.

Table 5. Average environmental responsibility score based on gender

\begin{tabular}{ll}
\hline Gender & ER Score \\
\hline Male & 95.46 \\
Female & 98.70 \\
\hline
\end{tabular}

For the PEB variable, the average of female undergraduate students scores higher than that of male students. The average score of female students is 85.20 while that of male students is 84.00 , as shown in Table 6. The difference between the value of male and female students is 0.80 . This shows that PEB is influenced by gender in conformity with the other report (Ichsan, Sigit, \& Miarsyah, 2018; Vicente-Molina, Fernández-Sainz, \& Izagirre-Olaizola, 2018).

Table 6. Average pro-environmental behavior score based on gender

\begin{tabular}{ll}
\hline Gender & PEB Score \\
\hline Male & 84.00 \\
Female & 85.20 \\
\hline
\end{tabular}

Nearly $90 \%$ of the respondents, undergraduate biology students, were shown to have a high ER. This is because environmental knowledge and environmental problems in studying biology can produce students' self- 
awareness of the environment. A person's awareness to the environment depends on the knowledge of the environmental problem and everyone must be responsible for their respective environment (Chander \& Muthukrishnan, 2015; Chuang \& Huang, 2018; Istiana \& Awaludin, 2018; Juhanda \& Maryanto, 2018; Lee, Sung, Wu, Ho, \& Chiou, 2018; Suryanda, Azrai, \& Wari, 2016).

Among the indicator for $E R$, feeling guilty has the highest percentage of $42 \%$. This shows that guilt because of bad behavior towards the environment in undergraduate students plays the biggest role in generating a sense of responsibility towards the environment. When undergraduate students damage the environment, students would be feeling guilty, so students reduce their actions that damage the environment. The influence of guilt on someone can be a great behavioral motivator (Fitriani, Adisyahputra, \& Komala, 2018; Moghavvemi, Sulaiman, Jaafar, \& Kasem, 2018; Owens, Sadler, Barlow, \& Smith-Walters, 2017; Supriyatin, Nurnawati, \& Heryanti, 2016). The lowest dimension with a percentage of $19 \%$ is the dimension of responsibility assessment. Responsibility is an important thing if we talk about the environment (Azrai, Ernawati, \& Sulistianingrum, 2017; Choudri et al., 2017; Collado, Staats, \& Sancho, 2017; Istiana \& Awaludin, 2018; Schmitt et al., 2018).

Based on the results of the study, the data shows in a normal and homogeneous distribution. Correlation test results show that ER and PEB have a positive and significant relationship. The regression model was obtained $\hat{Y}=23.876+0.623 \mathrm{X}$ while the coefficient correlation was 0.469 which means there was a moderate correlation. This shows that the two variables studied have a moderate correlation. The results of this study indicate that the higher the ER the higher the PEB undergraduate student, while the lower the ER of students, the lower the PEB too. PEB can be well predicted by the ER. Students with low responsibility for the environment might have bad attitude to the environment (El Ghoul, Guedhami, Kim, \& Park, 2018; Koutsoukos, Fragoulis, \& Valkanos, 2015; Lai, 2018; Moisander, 2007; Sangroya \& Nayak, 2017)

ER and PEB are also influenced by demographic factors such as gender, age, and duration of education. ER scores and PEB scores for female undergraduate students were higher than for male undergraduate students. This is because women have a higher level of responsibility in protecting the environment and caring for others in taking responsibility for reducing environmental problems (Derevenskaia, 2014; Ertz, Karakas, \& Sarigöllü, 2016; Freed, 2018; Jonell et al., 2016; Kamerilova, Kartavykh, Ageeva, Veryaskina, \& Ruban, 2016). In many studies also found gender differences in perceptions of the environment. Ordinary women are trained early to be more expressive, sympathetic, nurturing, cooperative, independent, and helpful (Syabilla, Suryanda, \& Sigit, 2018; Vicente-Molina et al., 2018). In addition, environmental-related behaviors mostly occur at home, such as saving electricity, using recycled products, and buying household products (Arnold, Kibbe, Hartig, \& Kaiser, 2018; Kaiser \& Wilson, 2004; Matthes \& Wonneberger, 2014; McCarthy \& Liu, 2017).

The age range of undergraduate students in this study is 18-21 years. The highest ER and PEB score in this study was not obtained from 21-year-old students who were the highest age, but the highest ER score was obtained from 20-year students, while PEB was obtained from 19-year students. This is not consistent with the theory that older people are environments that behave better than younger ages. Older people play a more important role in PEB than younger humans (Han, Nelson, \& Kim, 2015; Havu-Nuutinen \& Niikko, 2014; Koutsoukos et al., 2015; Schmitt et al., 2018). The incompatibility of the results of this study with the theory can be caused by the close age range of the respondents so that it does not have a major influence on the ER and PEB scores (Jonell et al., 2016; Wong et al., 2018).

Based on the results of the study, the determination coefficient value of 0.221 obtained indicates that the ER variable contributes $22.1 \%$ to the PEB variable. While the other $77.9 \%$ of PEB is influenced by other factors in the form of external factors and other internal factors. External factors that can affect PEB such as sociocultural and economic factors (Akenii, 2014; Austgulen, 2016; Haanpää, 2007). If environmental norms in community groups are upheld, then the community will be more environmentally friendly. Likewise, vice versa, if the environmental norms in a group of people are ignored, people will be lazy to take care of the environment (Aslan, 2015; Collado et al., 2017; Ito \& Kawazoe, 2015; Nordin \& Alias, 2013; Wynveen \& Sutton, 2017).

In addition, economic factors play a role in making decisions for PEB. Students have a high need to support their lectures. While most students do not have their own income. Such problems can affect students not to have high PEB. Some PEB as a good behavior in protecting the environment must pay higher costs, such as choosing organic food products, using renewable energy sources such as solar panels, the price of bags is more expensive than plastic bags (Arafat, Jijakli, \& Ahsan, 2015; Diaz-Rainey \& Ashton, 2011; Gu, Chhajed, Petruzzi, \& Yalabik, 2015; Ichsan \& Mulyani, 2018; Strange et al., 2011)

\section{CONCLUSION}

The result of the present study indicates a positive relationship between ER and PEB in biology undergraduate students. Based on this study, it is concluded that increasing people to have a PEB is by letting 
them to recognize an ER. For the further studies, it is recommended to make measurements on other factors that influence students eco-friendly behavior, knowledge, and awareness.

\section{REFERENCES}

Akenji, L. (2014). Consumer scapegoatism and limits to green consumerism. Journal of Cleaner Production, 63, 13-23. doi: https://doi.org/10.1016/j.jclepro.2013.05.022

Arafat, H. A., Jijakli, K., \& Ahsan, A. (2015). Environmental performance and energy recovery potential of five processes for municipal solid waste treatment. Journal of Cleaner Production, 105, 233-240. doi: https: //doi.org/10.1016/j.jclepro.2013.11.071

Arnold, O., Kibbe, A., Hartig, T., \& Kaiser, F. G. (2018). Capturing the environmental impact of individual lifestyles: Evidence of the criterion validity of the general ecological behavior ccale. Environment and Behavior, 50(3), 350-372. doi: https://doi.org/10.1177/0013916517701796

Aslan, S. (2015). Is learning by teaching effective in gaining 21 st century skills? the views of pre-service science teachers. Kuram ve Uygulamada Egitim Bilimleri, 15(6), 1441-1457. doi: https://doi.org/10.1273 8/estp.2016.1.0019

Austgulen, M. H. (2016). Environmentally sustainable textile consumption-What characterizes the political textile consumers? Journal of Consumer Policy, 39(4), 441-466. doi: https://doi.org/10.1007/s10603015-9305-5

Aye, L., \& Widjaya, E. R. (2006). Environmental and economic analyses of waste disposal options for traditional markets in Indonesia. Waste Management, 26(10), 1180-1191. doi: https://doi.org/10.1016/j. wasman.2005.09.010

Azrai, E. P., Ernawati, E., \& Sulistianingrum, G. (2017). Pengaruh gaya belajar David Kolb (divergen, assimilator, convergen, accommodator) terhadap hasil belajar siswa pada materi pencemaran lingkungan. Biosfer: Jurnal Pendidikan Biologi, 10(1), 9-16. doi: https://doi.org/10.21009/biosferjpb.101.2

Bronfman, N. C., Cisternas, P. C., López-Vázquez, E., De la Maza, C., \& Oyanedel, J. C. (2015). Understanding attitudes and pro-environmental behaviors in a chilean community. Sustainability, $7(10)$, 14133-14152. doi: https://doi.org/10.3390/su71014133

Buzov, I. (2014). Social network sites as area for students' pro-environmental activities. Procedia - Social and Behavioral Sciences, 152, 1233-1236. doi: https://doi.org/10.1016/j.sbspro.2014.09.304

Chander, P., \& Muthukrishnan, S. (2015). Green consumerism and pollution control. Journal of Economic Behavior and Organization, 114, 27-35. doi: https://doi.org/10.1016/j.jebo.2015.02.013

Choudri, B. S., Baawain, M., Al-Zeidi, K., Al-Nofli, H., Al-Busaidi, R., \& Al-Fazari, K. (2017). Citizen perception on environmental responsibility of the corporate sector in rural areas. Environment, Development and Sustainability, 19(6), 2565-2576. doi: https://doi.org/10.1007/s10668-016-9855-y

Chuang, S. P., \& Huang, S. J. (2018). The effect of environmental corporate social responsibility on environmental performance and business competitiveness: The mediation of green information technology capital. Journal of Business Ethics, 150(4), 991-1009. doi: https://doi.org/10.1007/s10551016-3167-x

Collado, S., Staats, H., \& Sancho, P. (2017). Normative influences on adolescents' self-reported proenvironmental behaviors: The role of parents and friends. Environment and Behavior. doi: https://doi. org/10.1177/0013916517744591

Cooper, C., Larson, L., Dayer, A., Stedman, R., \& Decker, D. (2015). Are wildlife recreationists conservationists? linking hunting, birdwatching, and pro-environmental behavior. Journal of Wildlife Management, 79(3), 446-457. doi: https://doi.org/10.1002/jwmg.855

Derevenskaia, O. (2014). Active learning methods in environmental education of students. Procedia - Social and Behavioral Sciences, 131, 101-104. doi: https://doi.org/10.1016/j.sbspro.2014.04.086

Diaz-Rainey, I., \& Ashton, J. K. (2011). Profiling potential green electricity tariff adopters: Green consumerism as an environmental policy tool?. Business Strategy and the Environment, 20(7), 456-470. doi: https:/l doi.org/10.1002/bse.699

Du, X., Jian, W., Zeng, Q., \& Du, Y. (2014). Corporate environmental responsibility in polluting industries: Does religion matter?. Journal of Business Ethics, 124(3), 485-507. doi: https://doi.org/10.1007/s10551013-1888-7

Durr, E., Bilecki, J., \& Li, E. (Qie). (2017). Are beliefs in the importance of pro-environmental behaviors 
correlated with pro-environmental behaviors at a college campus?. Sustainability: The Journal of Record, 10(3), 204-210. doi: https://doi.org/10.1089/sus.2017.29105.ed

El Ghoul, S., Guedhami, O., Kim, H., \& Park, K. (2018). Corporate environmental responsibility and the cost of capital: International evidence. Journal of Business Ethics, 149(2), 335-361. doi: https://doi.org/10.100 7/s10551-015-3005-6

Ertz, M., Karakas, F., \& Sarigöllü, E. (2016). Exploring pro-environmental behaviors of consumers: An analysis of contextual factors, attitude, and behaviors. Journal of Business Research, 69(10), 39713980. doi: https://doi.org/10.1016/j.jbusres.2016.06.010

Fitriani, U., Adisyahputra, A., \& Komala, R. (2018). Eco-friendly website development in biology learning based on project activities on environmental pollution. Biosfer: Jurnal Pendidikan Biologi, 11(1), 32-46. doi: https://doi.org/10.21009/biosferjpb.11-1.4

Freed, A. (2018). The relationship between university students' environmental identity, decision-making process, and behavior. Environmental Education Research, 24(3), 474-475. doi: https://doi.org/10. 1080/13504622.2017.1320705

Gabarda-Mallorquí, A., Fraguell, R. M., \& Ribas, A. (2018). Exploring environmental awareness and behavior among guests at hotels that apply water-saving measures. Sustainability, 10(5), 1-15. doi: https://doi. org/10.3390/su10051305

Gu, W., Chhajed, D., Petruzzi, N. C., \& Yalabik, B. (2015). Quality design and environmental implications of green consumerism in remanufacturing. International Journal of Production Economics, 162, 55-69. doi: https://doi.org/10.1016/j.ijpe.2014.12.040

Haanpää, L. (2007). Consumers' green commitment: Indication of a postmodern lifestyle?. International Journal of Consumer Studies, 31(5), 478-486. doi: https://doi.org/10.1111/j.1470-6431.2007.00598.x

Hama, S. M., \& Hilal, N. N. (2017). Fresh properties of self-compacting concrete with plastic waste as partial replacement of sand. International Journal of Sustainable Built Environment, 6(2), 299-308. doi: https://doi.org/10.1016/j.jisbe.2017.01.001

Han, J. H., Nelson, C. M., \& Kim, C. (2015). Pro-environmental behavior in sport event tourism: Roles of event attendees and destinations. Tourism Geographies, 17(5), 719-737. doi: https://doi.org/10.1080/146166 88.2015.1084037

Havu-Nuutinen, S., \& Niikko, A. (2014). Finnish primary school as a learning environment for six-year-old preschool children. European Early Childhood Education Research Journal, 22(5), 621-636. doi: https:// doi.org/10.1080/1350293X.2014.969084

Ichsan, I. Z., \& Mulyani, S. W. W. (2018). Improving students' motoric skills through demonstration method in recycling plastic waste. JPBI (Jurnal Pendidikan Biologi Indonesia), 4(2), 189-194. doi: https://doi. org/10.22219/jpbi.v4i2.5890

Ichsan, I. Z., Sigit, D. V., \& Miarsyah, M. (2018). Learning environment: Gender profile of students' ProEnvironmental Behavior (PEB) based on Green Consumerism. Tadris: Jurnal Keguruan Dan IImu Tarbiyah, 3(2), 97-107. doi: https://doi.org/10.24042/tadris.v3i2.3358

Ichsan, I. Z., Sigit, D. V., Miarsyah, M., Azrai, E. P., \& Heryanti, E. (2019). Students' pro-environmental behavior and environmental learning outcomes based on green consumerism. Jurnal Pendidikan Biologi Indonesia, 5(1), 109-116. doi: https://doi.org/10.22219/jpbi.v5i1.6447

Istiana, R., \& Awaludin, M. T. (2018). Enhancing biology education students ability to solve problems in environmental science material through inquiri model-based lesson study. Biosfer: Jurnal Pendidikan Biologi, 11(1), 57-66. doi: https://doi.org/10.21009/biosferjpb.11-1.6

Ito, H., \& Kawazoe, N. (2015). Active learning for creating innovators: Employability skills beyond industrial needs. International Journal of Higher Education, 4(2), 81-91. doi: https://doi.org/10.5430/ijhe.v4n2p81

Jonell, M., Crona, B., Brown, K., Rönnbäck, P., \& Troell, M. (2016). Eco-labeled seafood: Determinants for (blue) green consumption. Sustainability, 8(9), 1-19. doi: https://doi.org/10.3390/su8090884

Juhanda, A., \& Maryanto, Y. (2018). The emergence of biological problems in electronic school books (bse) class $\mathrm{x}$ reviewed from the scientific knowledge domain of scientific literacy. Biosfer: Jurnal Pendidikan Biologi, 11(2), 121-125. doi: https://doi.org/10.21009/biosferjpb.v11n2.121-125

Kaiser, F. G., Ranney, M., Hartig, T., \& Bowler, P. A. (1999). Ecological behavior, environmental attitude, and feelings of responsibility for the environment. European Psychologist, 4(2), 59-74. doi: https://doi. org/10.1027//1016-9040.4.2.59

Kaiser, F. G., \& Wilson, M. (2004). Goal-directed conservation behavior: The specific composition of a general performance. Personality and Individual Differences, 36(7), 1531-1544. doi: https://doi.org/10.1016/j. 
paid.2003.06.003

Kamerilova, G. S., Kartavykh, M. A., Ageeva, E. L., Veryaskina, M. A., \& Ruban, E. M. (2016). Electronic informational and educational environment as a factor of competence-oriented higher pedagogical education in the sphere of health, safety and environment. International Journal of Environmental and Science Education, 11(13), 6185-6194. Retrieved from http://www.ijese.net/makale/786

Kanchanabhandhu, C., \& Woraphong, S. (2016). A model of solid waste management based multilateral cooperation in semi-urban community. International Journal of Environmental and Science Education, 11(12), 5762-5775. Retrieved from https://pdfs.semanticscholar.org/9f55/4e6ba88e92939613fca1938 87cfd96e0a722.pdf

Koutsoukos, M., Fragoulis, I., \& Valkanos, E. (2015). Connection of environmental education with application of experiential teaching methods: A case study from Greece. International Education Studies, 8(4), 2328. doi: https://doi.org/10.5539/ies.v8n4p23

Krettenauer, T. (2017). Pro-environmental behavior and adolescent moral development. Journal of Research on Adolescence, 27(3), 581-593. doi: https://doi.org/10.1111/jora.12300

Lai, C.-S. (2018). A study of fifth graders' environmental learning outcomes in taipei. International Journal of Research in Education and Science, 4(1), 252-262. https://files.eric.ed.gov/fulltext/EJ1170105.pdf

Lazaridou, D., Michailidis, A., \& Trigkas, M. (2018). Socio-economic factors influencing farmers' willingness to undertake environmental responsibility. Environmental Science and Pollution Research, 1-10. doi: https://doi.org/10.1007/s11356-018-2463-7

Lee, P.-S., Sung, Y.-H., Wu, C.-C., Ho, L.-C., \& Chiou, W.-B. (2018). Using episodic future thinking to preexperience climate change increases pro-environmental behavior. Environment and Behavior, 001391651879059. doi: https://doi.org/10.1177/0013916518790590

Lekakos, G., Vlachos, P., \& Koritos, C. (2014). Green is good but is usability better? Consumer reactions to environmental initiatives in e-banking services. Ethics and Information Technology, 16(2), 103-117. doi: https://doi.org/10.1007/s10676-014-9337-6

Margono, B. A., Potapov, P. V., Turubanova, S., Stolle, F., \& Hansen, M. C. (2014). Primary forest cover loss in indonesia over 2000-2012. Nature Climate Change, 4(8), 730-735. doi: https://doi.org/10.1038/ nclimate2277

Matthes, J., \& Wonneberger, A. (2014). The skeptical green consumer revisited: Testing the relationship between green consumerism and skepticism toward advertising. Journal of Advertising, 43(2), 115-127. doi: https://doi.org/10.1080/00913367.2013.834804

McCarthy, B., \& Liu, H. B. (2017). Food waste and the 'green' consumer. Australasian Marketing Journal, 25(2), 126-132. doi: https://doi.org/10.1016/j.ausmj.2017.04.007

Miller, A. M. M., \& Bush, S. R. (2015). Authority without credibility? Competition and conflict between ecolabels in tuna fisheries. Journal of Cleaner Production, 107, 137-145. doi: https://doi.org/10.1016/j. jclepro.2014.02.047

Moghavvemi, S., Sulaiman, A., Jaafar, N. I., \& Kasem, N. (2018). Social media as a complementary learning tool for teaching and learning: The case of youtube. International Journal of Management Education, 16(1), 37-42. doi: doi: https://doi.org/10.1016/j.ijme.2017.12.001

Moisander, J. (2007). Motivational complexity of green consumerism. International Journal of Consumer Studies, 31(4), 404-409. doi: https://doi.org/10.1111/j.1470-6431.2007.00586.x

Nordin, A. B., \& Alias, N. (2013). Learning outcomes and student perceptions in using of blended learning in history. Procedia - Social and Behavioral Sciences, 103, 577-585. doi: https://doi.org/10.1016/j.sbspro. 2013.10.375

Owens, D. C., Sadler, T. D., Barlow, A. T., \& Smith-Walters, C. (2017). Student motivation from and resistance to active learning rooted in essential science practices. Research in Science Education, 125. doi: https://doi.org/10.1007/s11165-017-9688-1

Panno, A., Giacomantonio, M., Carrus, G., Maricchiolo, F., Pirchio, S., \& Mannetti, L. (2017). Mindfulness, pro-environmental behavior, and belief in climate change: The mediating role of social dominance. Environment and Behavior, 50(8). doi: https://doi.org/10.1177/0013916517718887

Rezvani, Z., Jansson, J., \& Bengtsson, M. (2017). Cause i'll feel good! An investigation into the effects of anticipated emotions and personal moral norms on consumer pro-environmental behavior. Journal of Promotion Management, 23(1), 163-183. doi: https://doi.org/10.1080/10496491.2016.1267681

Sangroya, D., \& Nayak, J. K. (2017). Factors influencing buying behaviour of green energy consumer. Journal of Cleaner Production, 151, 393-405. doi: https://doi.org/10.1016/j.jclepro.2017.03.010 
Schmitt, M. T., Aknin, L. B., Axsen, J., \& Shwom, R. L. (2018). Unpacking the relationships between proenvironmental behavior, life satisfaction, and perceived ecological threat. Ecological Economics, 143, 130-140. doi: https://doi.org/10.1016/j.ecolecon.2017.07.007

Song, Q., Li, J., Duan, H., Yu, D., \& Wang, Z. (2017). Towards to sustainable energy-efficient city: A case study of Macau. Renewable and Sustainable Energy Reviews, 75(August), 504-514. doi: https://doi. org/10.1016/j.rser.2016.11.018

Steinhorst, J., \& Klöckner, C. A. (2017). Effects of monetary versus environmental information framing: Implications for long-term pro-environmental behavior and intrinsic motivation. Environment and Behavior. doi: https://doi.org/10.1177/0013916517725371

Strange, N., Jellesmark, B., Bladt, J., Wilson, K. A., \& Rahbek, C. (2011). Conservation policies and planning under climate change. Biological Conservation, 144(12), 2968-2977. doi: https://doi.org/10.1016/j.bio con.2011.08.022

Supriyatin, S., Nurnawati, N., \& Heryanti, E. (2016). Pengaruh penerapan Active, Joyful, And Effective Learning (AJEL) pada materi perubahan lingkungan terhadap sikap peduli lingkungan siswa. Biosfer: Jurnal Pendidikan Biologi, 9(2), 69-75. doi: https://doi.org/10.21009/biosferjpb.9-2.10

Suryanda, A., Azrai, E. P., \& Wari, N. (2016). Pengaruh penerapan model pembelajaran Group Investigation (GI) terhadap kemampuan berpikir analisis siswa pada materi pencemaran lingkungan. Biosfer: Jurnal Pendidikan Biologi, 9(2), 37-44. doi: https://doi.org/10.21009/biosferjpb.9-2.6

Syabilla, Y. A., Suryanda, A., \& Sigit, D. V. (2018). A correlation between self concept and procrastination based on gender in neuroscience perspective. Biosfer: Jurnal Pendidikan Biologi, 11(2), 114-120. doi: https://doi.org/10.21009/biosferjpb.v11n2.114-120

Tang, Y., Geng, L., Schultz, P. W., Zhou, K., \& Xiang, P. (2017). The effects of mindful learning on proenvironmental behavior: A self-expansion perspective. Consciousness and Cognition, 51, 140-148. doi: https://doi.org/10.1016/j.concog.2017.03.005

Vicente-Molina, M. A., Fernández-Sainz, A., \& Izagirre-Olaizola, J. (2018). Does gender make a difference in pro-environmental behavior? The case of the Basque Country University students. Journal of Cleaner Production, 176, 89-98. doi: https://doi.org/10.1016/j.jclepro.2017.12.079

Wong, C. W. Y., Miao, X., Cui, S., \& Tang, Y. (2018). Impact of corporate environmental responsibility on operating income: Moderating role of regional disparities in China. Journal of Business Ethics, 149(2), 363-382. doi: https://doi.org/10.1007/s10551-016-3092-z

Wynveen, C. J., \& Sutton, S. G. (2017). Engaging great barrier reef stakeholders: Mediation analyses of barriers among the antecedents of pro-environmental behavior. Human Dimensions of Wildlife, 22(2), 126-141. doi: https://doi.org/10.1080/10871209.2016.1265185 